\title{
Intercellular Adhesion Molecule 3
}

National Cancer Institute

\section{Source}

National Cancer Institute. Intercellular Adhesion Molecule 3. NCI Thesaurus. Code

C17504.

Intercellular adhesion molecule 3 (547 aa, $60 \mathrm{kDa}$ ) is encoded by the human ICAM3 gene. This protein plays a role in both leukocyte adhesion and integ rin binding. 